\title{
Legal Protection For Parties In Economic Transactions Through Instagram
}

\author{
Anita Afrelia ${ }^{*}$ and Lathifah Hanim ${ }^{* *}$ ) \\ *)Master of Law Science Program, Faculty of Law, Universitas Islam Sultan Agung \\ Email: anitaafrel@gmail.com \\ **) Faculty of Law Universitas Islam Sultan Agung
}

\begin{abstract}
Economic online has the function of integration of marketing, implementation of $E$ Commerce strategies, the main purpose of increasing the number of sales. The formulation of the problem in this thesis research are: 1) How is the validity of economic transactions through Instagram according to Act No. 19 of 2016 concerning Information and Electronic Transactions? 2) How is the legal protection for the parties in economic transactions through social media Instagram according to Act No. 19 of 2016 concerning Electronic Information and Transactions? The approach method used is Normative Juridical approach. From the results of this study, 1) The validity of economic transactions through Instagram according to Act No. 19 of 2016 concerning Information and Electronic Transactions can be declared valid and becomes the base of the implementation of a contract for both parties. 2) Legal protection for the parties in economic transactions through social media Instagram according to Act No. 19 of 2016 concerning Information and Electronic Transactions that against buyers who are injured in a sale and purchase dispute consists of litigation and nonlitigation.

Keywords: Legal Protection, Online, Online Buying and Selling Transactions
\end{abstract}

\section{Introduction}

This very significant development of the internet has caused many large and small companies to offer their merchandise via the internet. Electronic transactions in the business world have various forms, including electronic commerce or commonly known as E-Commerce and e-com. Electronic commerce can be interpreted grammatically, namely trading conducted electronically by using the internet as the medium ${ }^{1}$.

The internet is seen as an advertising medium that is cheaper, more efficient and effective than other media. This internet business strategy is known as ECommerce. Online business through an E-Commerce application system is very efficient. They can exchange data and information with other companies through the EDI (Electronic Data Interchange) mechanism, or communicate with customers (Business to Customer). ${ }^{2}$

Economic online has an integration function of marketing, implementing ECommerce strategies besides aiming to maintain and increase the number of customers, the main goal is to increase the number of sales. Indonesia is now starting to be trusted again by the international community to make payments

\footnotetext{
${ }^{1}$ Ajibah, Nur Azizatil, 2004, Perlindungan Konsumen Dalam Transaksi Melalui E-Commerce", Jurisprudence,Vol. 1, March 2004, p. 29

${ }^{2}$ Andi Sunarto, Seluk Beluk E-Commerce: Panduan Bagi Pemula untuk Menjual Produknya Melalui Internet, Garailmu, Yogyakarta, 2009, p. 16
} 
online because the number of crimes via the internet has also begun to decrease and online transactions in Indonesia ${ }^{3}$.

This economic transaction via the internet is carried out without face to face between the parties. They base the transaction on mutual trust, so that the sale and purchase agreement between the parties is also carried out electronically by accessing the web page provided, containing clauses or agreements made by the first party (seller), and the other party (the buyer) only needs to press the button provided as a sign of approval of the existing agreement ${ }^{4}$.

The form of a sale and purchase agreement is a series of rights and obligations of both parties, which promise each other, namely the seller and the buyer. The sale and purchase agreement is regulated in Article 1457 to Article 1540 of the Civil Code. From the understanding according to Article 1457 of the Civil Code above, it can be concluded that economic is a reciprocal agreement, whereby the seller promises to give up property rights over an item and the buyer promises to pay an amount of money in return. The sale and purchase agreement is deemed to have occurred between the two parties, immediately afterwards these people reach an agreement on the material and its price, even though the material has not been submitted, nor has the price been paid (Article 1458 of the Civil Code) ${ }^{5}$.

Economic via the internet which is currently still widely found around us, namely economic transaction agreements that make it easier for consumers. This is because the internet is a very global computerized network. This economic business activity on the internet is called E-Commerce. "The E-Commerce agreement which is now a trend (people's attention or being favored by many) on the one hand provides benefits while on the other hand it does not guarantee and protect the rights of its consumers. ${ }^{6}$ Basically the concept of E-Commerce using this method is just a matter of advertising. The concept of economic is similar to the concept in traditional markets. The market will be more famous if it has many sellers and many buyers. The more sellers, the more complete the products sold, so that more buyers will come ${ }^{7}$.

One type of E-Commerce business activity is a shop on Instagram, a shop is a shopping site without meeting directly between the two parties (sellers and buyers) to make transactions". ${ }^{8}$ One example of fraud on Instagram starts with a cheap promo for the HP Oppo F7 brand which is sold for IDR 800 thousand on an Instagram account called @galery_rahbanishopping. In fact, the cellphone is in the market for above IDR. 3 million. The shop's existence is real and appropriate on Instagram. Both the address and telephone number listed also match what is

\footnotetext{
${ }^{3}$ Nugroho, Adi. 2006. E-Commerce Memahami Perdagangan Di Dunia Maya. Bandung: Informatika, p. 11

${ }^{4}$ Gultom, Elisatris dan Dikdik M. Arif Mansur. 2005. Cyber Law Aspek Hukum Teknologi Informasi. Bandung: PT Refika Aditama, p. 27

${ }_{5}^{5}$ Mariam Darus Badrulzaman, KUHPERDATA Buku VI, Bandung: Alumni, 2016, p. 108-120

${ }^{6}$ Edhy Sutanta, Pengantar Teknologi Informasi Graha Ilmu, Yogyakarta: Gramedia, 2005, p. 536

7 Eko Sri Suhariyanto, Perbedaan Mendasar Onlline Shop dan Marketplace, https://uangteman.com/blog/berita-bisnis/perbedaan-mendasar-online-shop-dan-marketplace/ accessed on March 9, 2020.

8Hasan Sadili, 2010, Hukum Transaksi Jual Beli, Jakarta: Gaya Media Pratama, p. 67
} 
written on the wall of the Instagram account. The buyer then continues his purchase via whatsapp message to the existing number. There, he admitted that he was served by the two online shop admins. The sale and purchase was agreed upon, the buyer was then asked to transfer IDR. 800 thousand according to the advertisement. However, on the other hand, the admin again asked himself for an amount of money on the grounds of a deposit, so that the goods could be delivered, amounting to IDR 2.5 million. Anga agreed, he transferred the requested money through BCA Bank to the BNI Bank account number belonging to the online shop admin. The buyer was again asked to send a larger amount of remittance money". After IDR 2.5 million is finished. The person asked for another IDR.5.5 million, and I offered IDR.600 because according to the price of a cellphone in general, it was IDR.3.9 million". A month passed, the buyer did not receive the ordered goods. ${ }^{9}$

Examples of cases above are cases that often occur when economic transactions in addition to buying goods, they do not think about the consequences that will occur if they have a problem in making economic transactions on social media, because of the trust system between the seller and the buyer of the sale buying is done by looking at the picture of the goods / services so that they do not care about the quality of the goods / services to be purchased. They are immediately tempted by a relatively cheaper price and intend to buy it without paying attention to the security of the transaction. However, if there is a case, for example, having agreed to a transaction, once the money is transferred to a certain account, but the goods are not sent / given, does not match what is stated in the picture or photo of the item. If we look at the problems that exist above, then the action that must be taken by the community is to be more careful in making economic transactions, because there are many possibilities that can cause losses to buyers and sellers.

\section{Research Methods}

The method used in this research is a normative juridical approach. This normative juridical research examines the implementation or implementation of positive legal provisions (legislation) and contracts factually in every particular legal event that occurs in society in order to achieve predetermined goals. ${ }^{10}$ This research is descriptive analytical. With this analytical descriptive study, it is easy to find out problems (cases) that are related to other related phenomena or symptoms.

\section{Results And Discussion}

\subsection{The Validity of Sale and Purchase Transactions through Instagram according to Act No. 19 of 2016 concerning Electronic Information and Transactions}

The validity of trade agreements or trading contracts made through

\footnotetext{
${ }^{9}$ Sandhi Nurhartanto, Lagi, Warga Ponorogo Tertipu Jual Beli Online, https://jatimnow.com/baca12520-lagi-warga-ponorogo-tertipu-jual-beli-online, accessed on March 9, 2020

${ }^{10}$ Muhammad, 2004, Abdulkadir, Hukum dan Penelitian Hukum, Bandung: Citra Aditya Bakti, p. 134
} 
electronic systems. It has become a habit if every trade transaction agreement is always stated in an agreement or contract. Referring to civil theory in general, a transaction is a legal act that involves two parties who need each other in matters that have a certain economic value, and are usually realized through an agreement called a contract. ${ }^{11}$ Because the contract itself serves to secure a transaction ${ }^{12}$.

According to Wicaksana (2020), Examination of embezzlement suspects in positions in the Ciamis Police with Police Case Report Number: LP / 74 / B / III / 2019 / JBR / SPKT Res Ciamis, March 30 of 2019 on behalf of the OHT Bin JA reporter, namely as following: Crime Scene Examination, Investigation, Preparation of Minutes, Examination of evidence: Search, confiscation, expert statements, arrest or detention and examination of suspects, Resumes and submission of files Obstacles: not everyone knows, has heard of criminal acts of embezzlement who want to report to the authorities law (police), there is collusion of a neat series of cooperation from top to bottom in the crime of embezzlement in a position so that there is a conspiracy.

The sale and purchase transaction through the internet is carried out without face to face between the parties, so that the sale and purchase agreement between the parties is also carried out electronically, either by e-mail or other means. Economic transactions carried out through the internet cannot possibly stop, even every day the latest technology is always found in the internet world, while the protection and legal certainty for internet users is insufficient, thus efforts must be made to achieve legal balance under these conditions. Legal relations that occur in electronic economic transactions do not only occur between entrepreneurs and consumers, but also between the following parties:

\section{a. Business to Business \\ b. Customer to Customer \\ c. Customer to Business \\ d. Customer to Government}

In overcoming the above problems, the legal provisions contained in the Civil Code can still be applied to electronic economic transactions, among others, Article 1457 of the Civil Code. In Indonesian national civil law, the terms of the validity of the agreement are regulated in Article 1320 of the Civil Code, which contains 4 (four) conditions, namely an agreement between those who bind themselves, the ability of the parties to make an engagement, a certain object (the object of the agreement must be clear and can be implemented) and a cause that is allowed (does not violate the law, decency and public order). The four terms for the validity of this agreement also automatically apply to the sale and purchase agreement in electronic transactions. This is expressly stated in Article 47 of

\footnotetext{
${ }^{11}$ Hasanuddin Rahman, 2003, Contract Drafting Seri Ketrampilan Merancang Kontrak Bisnis, Bandung: Citra Aditya Bakti, p. 2.

12Peter Mahmud Marzuki, Kontrak Bisnis Internasional, Master of Law Lectures at Airlangga University, Surabaya, 2001, at Emilda Kuspraningrum, The Legality of Electronic Contracts in the ITE Law in terms of Article 1320 of the Civil Code and UNCITRAL Model Law On Electronic Commerce, Risalah HUKUM, Faculty of Law, Unmul Vol. 7, No. 2, December 2011, p. 182 - 194
} 
Government Regulation Number 82 of 2012 concerning Implementation of Electronic Systems and Transactions. ${ }^{13}$

A legal engagement or relationship conducted electronically by integrating the network of a computer-based information system with a communication system based on telecommunication-based networks and services, which is further facilitated by the existence of a global Internet computer network ( network of network). ${ }^{14}$

Losses experienced by sellers in economic transactions via the internet are carried out without face to face between the parties. They base the transaction on mutual trust, so that the sale and purchase agreement between the parties is also carried out electronically by accessing the web page provided, containing clauses or agreements made by the first party (the seller), and the other party (the buyer) only needs to press the button provided as a sign of agreement on the content of the existing agreement, without the need to sign as the agreement in general, but uses an electronic signature or digital signature so that the parties do not need to meet in person to enter into an agreement ${ }^{15}$.

Economic activity is a new way that is quite developing nowadays, because it can make it easier for consumers to meet their shopping needs. Trading is an option because it has advantages, including being more practical and easy and can be done at any time as long as you have an internet connection, but on the other hand it has a negative impact, namely the emergence of legal problems that can cause harm to consumers and producers. ${ }^{16}$

Economic has an integrated function of marketing, implementing ECommerce strategies besides aiming to maintain and increase the number of customers, the main goal is to increase the number of sales. ${ }^{17} \mathrm{Almost}$ all economic activities in the world, especially in Indonesia, use the internet media using electronic systems. One aspect of economic activity is in terms of interacting by means of systems. One aspect of economic activity is in terms of transacting using the internet, known as E-Commerce. 18

E-Commerce is one form of trade transactions that is most influenced by developments in information technology. Through this trade transaction, the concept of traditional markets (where sellers and buyers physically meet) transforms into the concept of telemarketing (long distance trading via the internet). E-Commerce has also changed the way consumers get the products they want. 19

13 Government Regulation Number 82 of 2012 concerning Implementation of Electronic Systems and Transactions, Article 47.

${ }^{14}$ Halim, Abduldan Teguh Prasetyo, 2006, Bisnis E-Commerce, Yogyakarta: Pustaka Pelajar, p. 14

${ }^{15}$ Gultom, Elisatris dan Dikdik M. Arif Mansur. 2005. Cyber Law Aspek Hukum Teknologi Informasi. Bandung: PT Refika Aditama, p. 27.

${ }^{16}$ Husni Syawali and Neni Sri Maniyati, 2000, Aspek Hukum Transaksi Online, Bandung: CV. Mandar Maju, Bandung, p. 41

${ }^{17}$ Faisal, Mengingat Dominasi Positivisme Hukum, Jurnal Hukum Progresif Vol.4 No.1 of 2010, p. 128.

${ }^{18}$ Rahadi Wasi Bintoro, Peranan Hukum Dalam Penyelesaian Sengketa Transaksi Elektronik Di Peradilan Umum, Jurnal Dinamika Hukum, Vol. 11 No.2 Of 2011, p. 259.

19 Alfan Perdana, dkk, Penyelesaian Wanpresatasi Dalam Perjanjian Jual Beli Melalui Media Elektronik, Jurnal Ilmu Hukum, Vol.2 No.10f 2014, p. 52. 
The development of information technology, including the internet, also presents its own challenges for legal development. Laws in Indonesia are required to adapt to social changes that occur. ${ }^{20}$ In principle, trade transactions using ECommerce technology are actually a contract model that is the same as conventional economic contracts carried out in society. Until now, the conventional economic carried out by the community is based on the Civil Code system and according to the customary law system. According to Indonesian customary law, what is called economic, is not a mere agreement between the two parties, but is a delivery of goods by the seller to the buyer with the intention of transferring property rights over the goods on the condition of payment of a certain price, in the form of money by the buyer to the seller. Thus, in customary law, every economic relationship is not binding on any principle or system of obligators or other systems / principles. ${ }^{21}$

The very rapid growth of internet users has made the internet a very effective medium for carrying out trading activities. Advances in information technology are increasingly fast demanding dynamic developments in the field of law that regulates them. The enactment of the Information and Electronic Transactions Law (Act No. 19/2016 - ITE Law) addresses the need for regulating and protecting business transactions conducted via the internet. Protection of business transactions is very important considering that there are a lot of electronic contracts which are a form of business product that are specifically protected in the ITE Law, especially Article 1 point 17 which states that Electronic Contracts are agreements of the parties made through electronic systems jo, Article 18 paragraph (1). ${ }^{22}$

\subsection{Actions of the Land Office in implementing Act No. 56 (Prp) of 1960 concerning the Determination of the Area of Agricultural Land So that it Works Effectively in Kendal Regency}

The development of E-Commerce trade is growing rapidly. In addition to having a positive impact on the development and growth of the Indonesian economy, it will also cause problems which of course must be found a way to solve them using the prevailing laws and regulations in Indonesia.

For the people of Indonesia this is related to a very important legal issue. The importance of legal issues in the field of E-Commerce is especially in providing protection for parties who conduct transactions via the internet. ${ }^{23}$ Given the importance of this, Indonesia in 2016 issued a special regulation regulating transactions via the internet, namely Act No. 19 of 2016 concerning Electronic Information and Transactions, hereinafter abbreviated as the ITE Law.

\footnotetext{
20 Syaifullah Noor, dkk, Informasi Dan Transaksi Elektronik Dikaitkan Dengan Kebebasan Berekspresi, Jurnal Ilmu Hukum, Vol.3 No 3 Of 2015, p. 69.

21 Atip Latifulhayat, Perlindungan Data Pribadi dalam Perdagangan Secara Elektronik (ECommerce), Article in Jurnal Hukum Bisnis, Volume 18 March 2002, p. 28.

${ }^{22}$ Daniel, Perjanjian Jual Beli Melalui Internet (E-Commerce) Ditinjau Dari Aspek Hukum Perdata, Yogyakarta: Universitas Atma Jaya, 2015, p.. 18

${ }^{23}$ Lia Sautunnida, 2008, Jual Beli Melalui Internet (E-Commerce) Kajian Menurut Buku III KUH Perdata dan Undang-Undang Informasi dan Transaksi Elektronik, Faculty of Law University of Syiah Kuala, p. 1
} 
In Article 38 of Act No. 11 of 2008 concerning Electronic Information and Transactions itself affirms that the public can file a lawsuit in a representative manner against the party that operates Electronic Systems and / or uses Information Technology which results in harm to the public, in accordance with the provisions of the Legislation. Furthermore, Article 39 of Act No. 19 of 2016 concerning Electronic Information and Transactions, this is in accordance with the provisions in Article 23 of Act No. 8 of 1999 concerning Consumer Protection. According to applicable law in Indonesia, a civil lawsuit can be based on two reasons, namely default and unlawful acts (Onrechtmatigedaad). The legal basis is based on the provisions of Book III article 1243 BW for defaults and Article 1365 BW for illegal acts.

A claim for default always starts with a contractual legal relationship (agreement) between the parties, thus giving birth to legal rights and obligations. The rights and obligations here are manifested by what is known as performance. When the achievement is not fulfilled / not implemented / implemented improperly according to the agreement of the parties, then what is called default (default) is born. Whereas in a lawsuit against the law, the basis for the lawsuit is the interests of certain parties that are harmed by the actions of other parties, even though there is no civil law relationship between the parties that is contractual in nature (agreement).

If E-Commerce crime has entered into the realm of crime, the provisions in Indonesian legislation have regulated it, namely in Act No. 11 of 2008 concerning Electronic Information and Transactions, among others in Article 30. Furthermore, the legal provisions are contained in Article 46 of Act No. 11 of 2008 concerning Electronic Information and Transactions. The Consumer Protection Law regulates consumer rights, Article 4 of Act No. 8 of 1999 concerning Consumer Protection.

On the other hand, the obligations for business actors (in this case are sellers), are in accordance with Article 7 of Act No. 8 of 1999 concerning Consumer Protection. Article 8 of Act No. 8 Year 1999 concerning Consumer Protection prohibits business actors from trading goods / services that are not in accordance with the promises stated in labels, tags, information, advertisements or sales promotions of the said goods and / or services. Based on this article, the mismatch between the specifications of the goods you receive and the goods listed in the advertisement / photo offering of goods is a form of violation / prohibition for business actors in trading goods. You as a consumer in accordance with Article 4 letter h Act No. 8 of 1999 concerning Consumer Protection are entitled to compensation,

Based on Article 49 paragraph (3) PP PSTE specifically regulates this matter, namely Business Actors are required to give a time limit to consumers to return goods sent if they do not comply with the agreement or there are hidden defects. In addition to the two provisions above, if it turns out that the goods you receive do not match the photo on the shop advertisement (as a form of offer), you can also sue the Business Actor (in this case the seller) on a civilian basis on the pretext of a misinterpretation of the sale and purchase transaction that you do with the seller.

Even consumer protection laws related to economic transactions, as we previously explained, are no different from the laws that apply to real economic transactions. The difference is only in the use of internet or other 
telecommunication facilities. The result is that in economic transactions it is difficult to execute or take concrete action in the event of a dispute or a criminal act of fraud. The nature of cyber in electronic transactions allows every person, both seller and buyer, to disguise or falsify their identity in every transaction or sale and purchase agreement.

In the event that a business actor or seller is using a false identity or committing deception in the sale and purchase, the business actor can also be convicted under Article 378 of the Criminal Code regarding fraud and Article 28 paragraph (1) of the ITE Law. About spreading false and misleading news that results in consumer losses in Electronic Transactions.

Actions as described in Article 28 paragraph (1) of the ITE Law are punishable by imprisonment for a maximum of 6 (six) years and / or a maximum fine of IDR. 1 billion (Article 45 paragraph [2] of the ITE Law). Based on the above matters, settlement of disputes in electronic trade transactions can be carried out both civil and criminal, thereby providing a legal umbrella for the people of Indonesia.

The form of legal protection for buyers in economic disputes is regulated in BW jo. Act No. 19 of 2016 jo. PP No. 82 of 2012 jo. BW. Act No. 8 of 1999 regulates default (Article 1243 BW) Act No. 19 of 2016 regulates electronic documents as evidence (Article 5 of the ITE Law). PP No. 82/2012 regulates the validity of electronic contracts (Article 47 PP No 82/2012).

Article 4 letter (e) of UUPK regulates consumer rights, namely the right to obtain advocacy, protection and efforts to properly resolve consumer protection disputes. However, in the above case, Agung as the consumer did not use his rights properly. Article 45 paragraph (1) of this Law also states that every consumer who is harmed can sue business actors through an institution that is tasked with resolving disputes between consumers and business actors or through courts located within the general court. Whereas it is clearly regulated in the Law regarding consumer rights attached to Agung and they can also sue business actors who harm them ${ }^{24}$.

\section{Closing}

Economic has an integrated function of marketing, implementing ECommerce strategies besides aiming to maintain and increase the number of customers, the main goal is to increase the number of sales. Almost all economic activities in the world, especially in Indonesia, use the internet media using electronic systems. One aspect of economic activity is in terms of interacting by means of a system. One aspect of economic activity is in terms of transacting using the internet which is known as E-Commerce and for the development of ECommerce trade is growing rapidly. In addition to having a positive impact on the development and growth of the Indonesian economy, it will also cause problems which of course must be found a way to solve them using the prevailing laws and regulations in Indonesia.

\footnotetext{
${ }^{24}$ http://e-journal.uajy.ac.id/6633/2/HK110085.pdf, accessed on 13 July 2020
} 


\section{References}

\section{Book}

[1] Andi Sunarto, 2009, Seluk Beluk E-Commerce: Panduan Bagi Pemula untuk Menjual Produknya Melalui Internet, Garailmu, Yogyakarta

[2] Daniel, 2015, Perjanjian Jual Beli Melalui Internet (E-Commerce) Ditinjau Dari Aspek Hukum Perdata, Yogyakarta: Universitas Atma Jaya

[3] Edhy Sutanta, Pengantar Teknologi Informasi Graha Ilmu, Yogyakarta: Gramedia, 2005

[4] Gultom, Elisatris dan Dikdik M. Arif Mansur. 2005. Cyber Law Aspek Hukum Teknologi Informasi. Bandung: PT Refika Aditama

[5] Halim, Abduldan Teguh Prasetyo, 2006, Bisnis E-Commerce, Yogyakarta: Pustaka Pelajar, p. 14

[6] Hasan Sadili, 2010, Hukum Transaksi Jual Beli, Jakarta: Gaya Media Pratama

[7] Hasanuddin Rahman, 2003, Contract Drafting Seri Ketrampilan Merancang Kontrak Bisnis, Bandung: Citra Aditya Bakti

[8] Husni Syawali and Neni Sri Maniyati, 2000, Aspek Hukum Transaksi Online, Bandung: CV. Mandar Maju, Bandung

[9] Lia Sautunnida, 2008, Jual Beli Melalui Internet (E-Commerce) Kajian Menurut Buku III KUH Perdata dan Undang-Undang Informasi dan Transaksi Elektronik, Faculty of Law University of Syiah Kuala

[10] Mariam Darus Badrulzaman, KUHPERDATA Buku VI, Bandung: Alumni, 2016

[11] Muhammad, 2004, Abdulkadir, Hukum dan Penelitian Hukum, Bandung: Citra Aditya Bakti

[12] Nugroho, Adi. 2006. E-Commerce Memahami Perdagangan Di Dunia Maya. Bandung: Informatika

\section{Regulations}

[1] Constitution of Indonesian Republic 1945

[2] Code of Civil law

[3] Act No. 19 of 2016 concerning Amendments to the ITE Law

[4] Act No. 11 of 2008 concerning Electronic Information and Transactions

[5] Act No. 8 of 1999 concerning Consumer Protection

[6] Government Regulation Number 82 of 2012 concerning Implementation of Electronic Systems and Transactions

\section{Journals}

[1] Ajibah, Nur Azizatil, 2004, Perlindungan Konsumen Dalam Transaksi Melalui E-Commerce", Jurisprudence,Vol. 1, March 2004

[2] Alfan Perdana, dkk, Penyelesaian Wanpresatasi Dalam Perjanjian Jual Beli Melalui Media Elektronik, Jurnal Ilmu Hukum, Vol.2 No.10f 2014

[3] Atip Latifulhayat, Perlindungan Data Pribadi dalam Perdagangan Secara Elektronik (E-Commerce), Article in Jurnal Hukum Bisnis, Volume 18 March 2002

[4] Faisal, Mengingat Dominasi Positivisme Hukum, Jurnal Hukum Progresif Vol.4 No.1 of 2010 
[5] Peter Mahmud Marzuki, Kontrak Bisnis Internasional, Master of Law Lectures at Airlangga University, Surabaya, 2001, at Emilda Kuspraningrum, The Legality of Electronic Contracts in the ITE Law in terms of Article 1320 of the Civil Code and UNCITRAL Model Law On Electronic Commerce, Risalah HUKUM, Faculty of Law, Unmul Vol. 7, No. 2, December 2011

[6] Rahadi Wasi Bintoro, Peranan Hukum Dalam Penyelesaian Sengketa Transaksi Elektronik Di Peradilan Umum, Jurnal Dinamika Hukum, Vol. 11 No.2 Of 2011

[7] Syaifullah Noor, dkk, Informasi Dan Transaksi Elektronik Dikaitkan Dengan Kebebasan Berekspresi, Jurnal Ilmu Hukum, Vol.3 No 3 of 2015

\section{Internet}

[1] Sandhi Nurhartanto, Lagi, Warga Ponorogo Tertipu Jual Beli Online, https://jatimnow.com/baca-12520-lagi-warga-ponorogo-tertipu-jual-belionline, accessed on March 9, 2020

[2] http://e-journal.uajy.ac.id/6633/2/HK110085.pdf, accessed on 13 July 2020

[3] Eko Sri Suhariyanto, Perbedaan Mendasar Onlline Shop dan Marketplace, https://uangteman.com/blog/berita-bisnis/perbedaan-mendasar-onlineshop-dan-marketplace/ Accessed on March 9, 2020. 